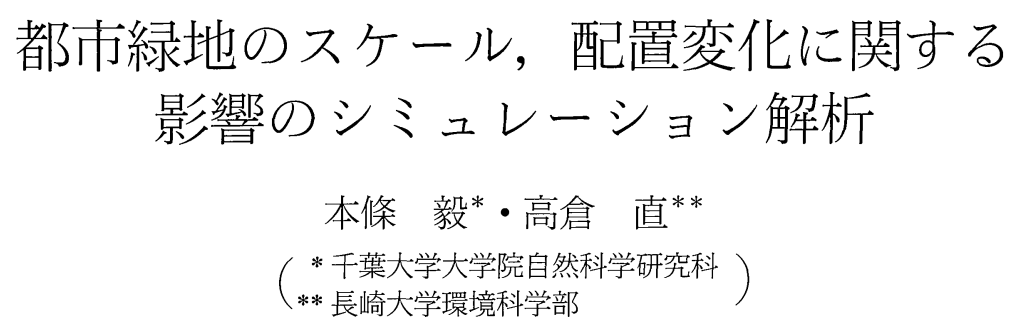

\title{
Simulation of the Influence of Urban Green Areas with Various Scales and Allocation
}

\author{
Tsuyoshi Honjo* and Tadashi TAKaKURA**
}

$\left(\begin{array}{c}* \text { Graduate School of Science and Technology, Chiba University, Inage-ku, Chiba, 263-8522 Japan } \\ * * \text { Faculty of Environmental Studies, Nagasaki University, Nagasaki, 852-8521 Japan }\end{array}\right)$

\begin{abstract}
In this study a two dimensional $k-\varepsilon$ two equation model was used with the equations of temperature and normalized humidity to analyze the thermal effect of urban green areas. The relation between the scale of an urban green area and its influence and the relation between the interval of an urban green area and its influence were analyzed.

The relation of scale of a green area and its influence on the surrounding urban area is not clear, although many micrometeorological measurements of urban green areas have indicated that a large scale of green area influences a large urban area. The relation of the interval between green areas and its effect on the surrounding urban area is also unclear.

With respect to the relation between scale of urban green area and its influence, at the lowest simulated altitude of $2 \mathrm{~m}$ sudden decreases in temperature and sudden increases in normalized humidity were observed at the upwind edge of green areas. In the adjacent urban area downwind of green areas, rapid increases in temperature and rapid decreases in normalized humidity were found. At the height of $6 \mathrm{~m}$, the changes were smoother.

From the distribution of temperature and normalized humidity, it is observed that a green area of larger scale influences a higher area. From the distribution of diffusivity, a large value was observed at the transition area from green area to urban area and this tendency was the same in the case of two green areas. On the relation of interval between green areas and its influence, low temperature and high humidity were observed in the urban area between two green areas. These results show that the two green areas with optimal interval affect the temperature and humidity near the ground effectively.
\end{abstract}

Key words: Interval of green area, $k-\varepsilon$ two equation model, Scale of green area, Simulation, Turbulent model.

キーワード: $k-\varepsilon 2$ 方程式モデル, シミュレーション, 乱流モデル, 緑地間隔, 緑地規模

\section{1. はじめに}

都市緑地による周囲への影響については，様々な観測 例があり，緑地の規模が大きいほど，周囲への影響む大 きい傾向があることが示唆されている（例えば, Honjo

1990 年 8 月 8 日 全国大会にて発表

1999 年 11 月 25 日 受付, 2000 年 6 月 26 日受理 and Takakura, 1984; 1986; Yun et al., 1998)。しか

し, 微気象観測などから得られるデー夕は, 時間的にも 空間的にあ限界があり, 緑地のスケールと緑地の影響と の関係を予測するためには，シミュレーションモデルを 用いた分析が必要である。

また，同面積の緑地をどのように配置すれば，効率的 に周囲に影響を及ぼすことができるかなどについては， 


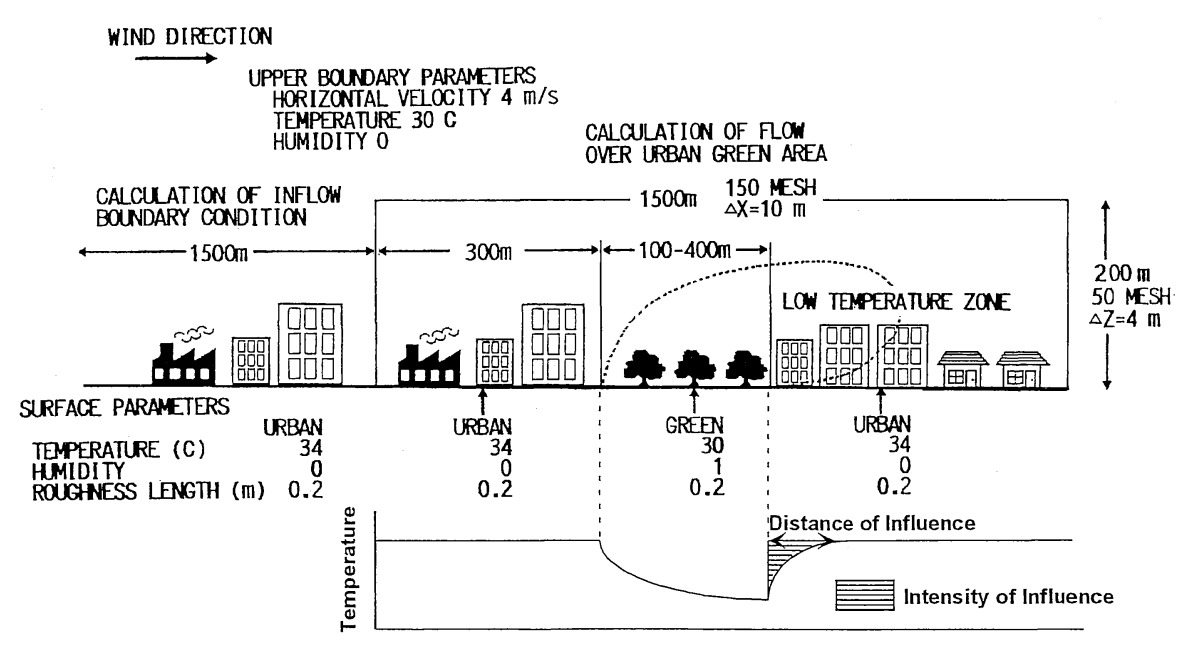

Fig. 1. Diagram of the thermal effect of an urban green area and parameters used in the simulation.

測定例は非常に少ない。測定の適地が少ないことや，測 定の空間的密度や回数には限界があるため, 様々な条件 を想定した定量的予測には，同様にシミュレーションモ デルを用いた分析が必要であるが，緑地の配置などにつ いてのシミュレーションによる研究例はほとんどない。

そこで, 本研究では, シミュレーションにより, 特に 緑地のスケールが変化したときの周囲への影響，複数の 緑地が存在し，緑地間隔が変化したときの周囲への影響 について解析を行った。

流体シミュレーションモデルは，天気予報に用いられ る数值予報モデルや，建築での室内外の気流シミュレー ションなど非常に多くの分野で用いられている。比較的 小規模な気象現象のモデルとしては, 海陸風, 湖陸風 のシミュレーション (Estoque, 1961; Estoque and Bhumralkar, 1969; Bill et al., 1979), ヒートアイラ ンドのシミュレーション (McElroy, 1973; Lee and Olfe, 1974; Bornstein, 1975; Gutman and Torrance, 1975; Yu and Wagner, 1975）など研究例が多い。都市 緑地による気温低下のシミュレーションモデルは, Honjo and Takakura (1990/1991), Kanda and Hino （1990）などにより研究されている。

緑地の内外では，急激に地表面が変化するため大気の 運動量，熱，物質の拡散係数む大きく変化するもの之考 えられる。このような, 拡散係数のモデル化は, 乱流モ デルにより行うことができる。そこで，本研究では， Honjo and Takakura (1990/1991；2000）で報告した $k-\varepsilon 2$ 方程式モデルを用いて解析を行った。

\section{2. モ デル}

\section{1 モデルの概要}

モデルは，Fig. 1 の模式図のような緑地を含む都市平 面上を風が吹くとき, 都市-緑地-都市之地表の状態が変 るとと屯に変化する地表面温度, 湿度, 粗度上での風速, 温度，湿度などの分布を二次元で予測するものである。 計算領域は, 垂直方向 $200 \mathrm{~m}$, 水平方向 $1,500 \mathrm{~m}$ の 2 次 元の範囲とした。また，風上境界の風速プロファイルな ぞを計算するため，風上にも同様の計算領域をとった。

Fig. 1 には, 気温について本研究で用いた緑地の影響 の範囲 (distance of influence) や影響の強度の定義 （intensity of influence）あ示している。本研究では, 影 響の範囲は, 緑地の風下端から, 風下の都市部の気温が, 緑地風上の都市部の気温に回復する点までとし, 影響の 強度は，その間の気温差の積分值とした。

複数緑地の影響の範囲は, 緑地間の都市部でも風上の 都市部の気温以下であれば 緑地の影響を受けている範 囲に含まれるとした。

緑地の影響のシミュレーションでは, 都市などに比べ スケールが小さく, 水平方向の変化を知ることが重要で あることから，二次元あるいは三次元のモデルが必要で ある。本研究では，二次元モデルを使用した。緑地の特 徵は, 地表面の温度, 湿度, 粗度などの境界条件で設定 した。

本研究で用いた $k-\varepsilon 2$ 方程式モデルなどの基礎方程 式，境界条件は Honjo and Takakura（2000）同様，以 下に示すようなあのである。式中の変数の意味は, Table 1に示す。 
Table 1 Variables and parameters used for the simulation model.

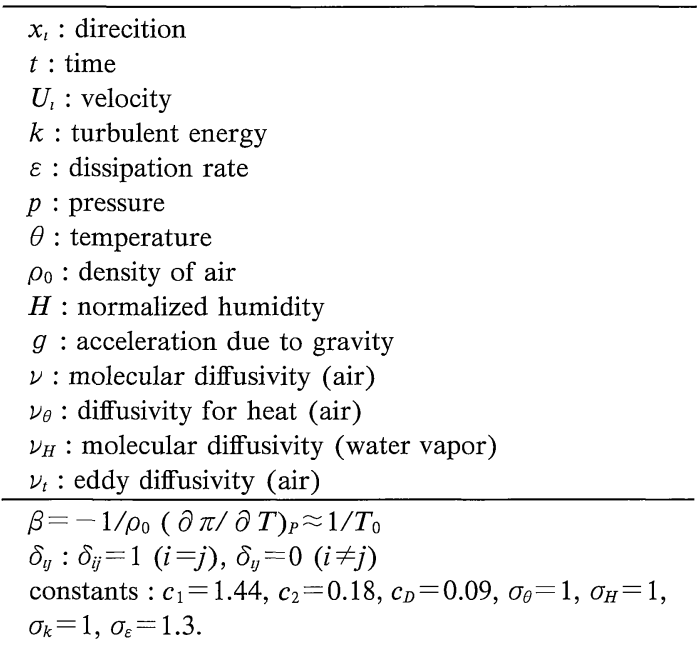

運動方程式

$$
\begin{aligned}
\frac{\partial U_{i}}{\partial t}+\frac{\partial U_{l} U_{j}}{\partial x_{j}}= & -\frac{\partial \pi}{\partial x_{j}}-\beta g \theta \delta_{i 3}+\frac{\partial}{\partial x_{j}}\left(\left(\nu_{t}+\nu\right)\right. \\
& \left.\cdot\left(\frac{\partial U_{i}}{\partial x_{j}}+\frac{\partial U_{J}}{\partial x_{i}}\right)\right)
\end{aligned}
$$

ただし

$$
\pi=\frac{p}{\rho_{0}}+\frac{2 k}{3}
$$

連続の式

$$
\frac{\partial U_{j}}{\partial x_{j}}=0
$$

エネルギー方程式

$$
\frac{\partial \theta}{\partial t}+\frac{\partial \theta U_{J}}{\partial x_{j}}=\frac{\partial}{\partial x_{j}}\left(\left(\frac{\nu_{t}}{\sigma_{\theta}}+\nu_{\theta}\right) \frac{\partial \theta}{\partial x_{j}}\right)
$$

水蒸気などの拡散方程式

$$
\frac{\partial H}{\partial t}+\frac{\partial H U_{J}}{\partial x_{j}}=\frac{\partial}{\partial x_{J}}\left(\left(\frac{\nu_{t}}{\sigma_{H}}+\nu_{H}\right) \frac{\partial H}{\partial x_{j}}\right)
$$

乱流エネルギー方程式

$$
\begin{aligned}
\frac{\partial k}{\partial t}+\frac{\partial k U_{J}}{\partial x_{j}}= & \frac{\partial}{\partial x_{J}}\left(\left(\frac{\nu_{t}}{\sigma_{k}}+\nu\right) \frac{\partial k}{\partial x_{J}}\right) \\
& +\nu_{t} S-\varepsilon+\frac{\beta g}{\sigma_{\theta}} \nu_{t} \frac{\partial \theta}{\partial x_{3}}
\end{aligned}
$$

ただし，

$$
\mathrm{S}=\left(\frac{\partial U_{i}}{\partial x_{j}}+\frac{\partial U_{j}}{\partial x_{l}}\right) \frac{\partial U_{i}}{\partial x_{j}}
$$

粘性消散率方程式

$$
\frac{\partial \varepsilon}{\partial t}+\frac{\partial \varepsilon U_{j}}{\partial x_{j}}=\frac{\partial}{\partial x_{j}}\left(\left(\frac{\nu_{t}}{\sigma_{\varepsilon}}+\nu\right) \frac{\partial \varepsilon}{\partial x_{\jmath}}\right)
$$

Table 2 Cases of the simulation. Location of green areas indicates the horizontal distance from the inflow boundary in a horizontal direction in Fig. 1.

\begin{tabular}{cc}
\hline Scale of green area & Location of green area \\
\hline $100 \mathrm{~m}$ & $300-400 \mathrm{~m}$ \\
$200 \mathrm{~m}$ & $300-500 \mathrm{~m}$ \\
$300 \mathrm{~m}$ & $300-600 \mathrm{~m}$ \\
$400 \mathrm{~m}$ & $300-700 \mathrm{~m}$ \\
$100 \mathrm{~m} \times 2$ with $100 \mathrm{~m}$ interval & $300-400 \mathrm{~m}, 500-600 \mathrm{~m}$ \\
$100 \mathrm{~m} \times 2$ with $200 \mathrm{~m}$ interval & $300-400 \mathrm{~m}, 600-700 \mathrm{~m}$ \\
\hline \\
$+\frac{c_{1} \varepsilon}{k} \nu_{t} S-\frac{c_{2} k \varepsilon}{\nu_{t}}$
\end{tabular}

渦動粘性係数

$$
\nu_{t}=\frac{c_{D} k^{2}}{\varepsilon}
$$

本モデルでは, コントロールボリューム法を用い, メッシュは風速とその他の変数が交互に位置するス夕 ガートメッシュを採用した。運動方程式の解法には MAC 法を用いた。移流項の空間差分の解法は, 風速に ついては中心差分を, その他の変数については風上差分 を用いた。時間差分には, 二次精度のアダムスバッシュ フォース法を用いた。

境界条件は, 上面, 地表面, 風上面, 風下面に分けて 以下のように設定した。

（1）上面, 風下面

境界での変化がないあのとした。

(2) 風上面

風速，温度，湿度については，垂直分布を与え，時間 的な変化はないものとした。その他は, (1) 同様, 境界 での变化がないとした。

（3）地表面

地表での境界条件は, wall-boundary 条件を用いた。

\section{2 シミュレーションケースの概要}

コンクリートなどで覆われた面の多い市街地を, 都市 部とよぶことにする。

シミュレーションに使用した緑地のスケールの值を,

Table 2 に示す。 基本的には Honjo and Takakura （1990/1991）で用いたの之同一のケースである。単独 の緑地の規模が変化した場合のケースと，2つの緑地を 含む都市平面上のケースがある。2つの緑地を含む場合 では, 都市部-緑地一都市部の变化が 2 度連続することに なる。

シミュレーションに使用したパラメータ值を Fig. 1 中に示す。想定したのは夏期の日中の場合で, 緑地の表 面温度は気温と同じ $30{ }^{\circ} \mathrm{C}$, 市街地の地表面は日射によ 


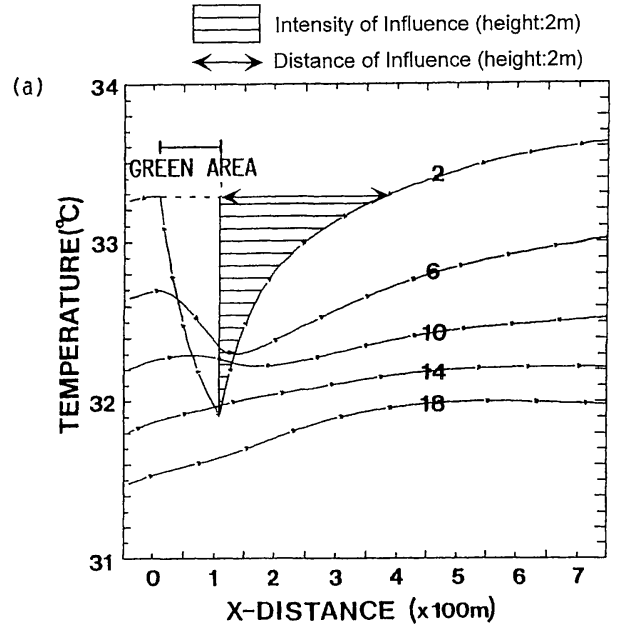

(b)

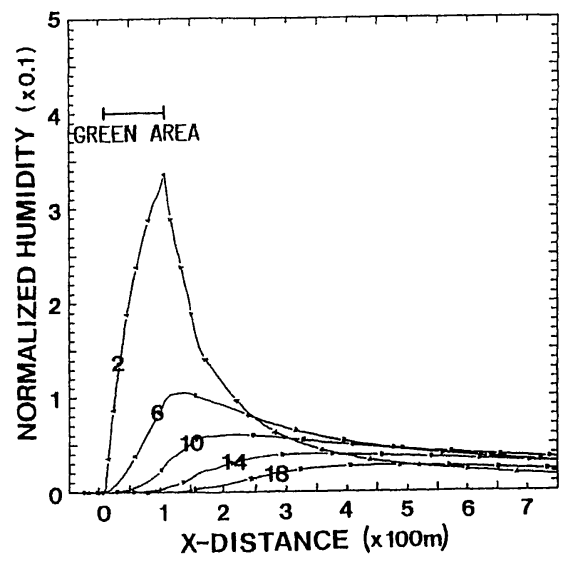

Fig. 2. Horizontal variation of (a) temperature and (b) normalized humidity near a green area (case of $100 \mathrm{~m}$ scale green area). The number on the line in Fig. 2 to 5 shows altitude in $\mathrm{m}$.

り高温となり $34{ }^{\circ} \mathrm{C}$ となるという状況である。湿度は, 絶対湿度（あるいは水蒸気圧）を正規化した值を用い， 湿った面である緑地上では 1 , 緑地に比べ乾燥した都市 部や上面境界では 0 とした。粗度長は, 低層の住宅地 と, 低木加らなる緑地を想定し, 都市部, 緑地ともにす べて $0.2 \mathrm{~m}$ とした。

シミュレーションの対象領域は, 水平方向に $150 \times ッ$ シュ $(1,500 \mathrm{~m})$, 垂直方向に 50 メッシュ $(200 \mathrm{~m})$ の実 線の長方形内である。緑地は, 単独の場合む複数の場合 屯, 計算領域の風下 $300 \mathrm{~m}$ 加ら配置されるように設定 した。

対象領域の風上に, 均一な $1,500 \mathrm{~m}$ の都市部地表面を 設定し, 計算領域の風上境界条件を計算した。この部分 の風上境界の風速, 温湿度の垂直分布は対数分布とした。 (a)

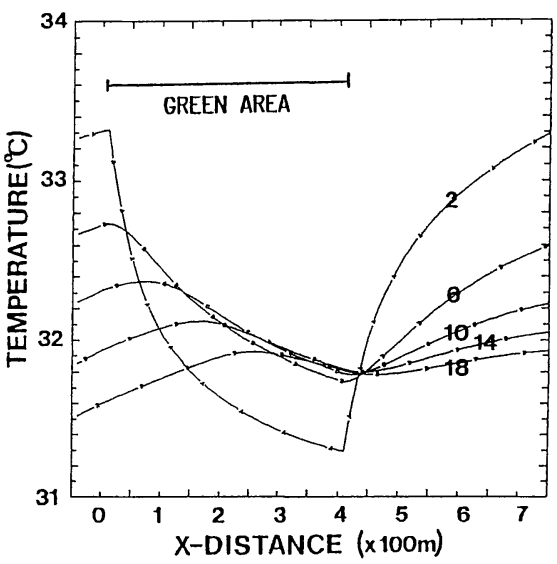

(b)

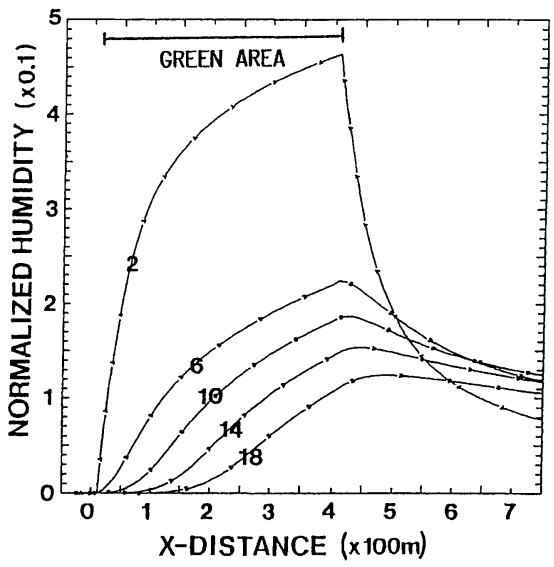

Fig. 3. Horizontal variation of (a) temperature and (b) normalized humidity near a green area (case of $400 \mathrm{~m}$ scale green area).

\section{3. 結果および考察}

\section{1 スケール緑地の異なる緑地上の温度と湿度の高 度別変化}

Fig. 2 に緑地スケール 100 m, Fig. 3 にスケール $400 \mathrm{~m}$ の場合の, 高さ $2 \mathrm{~m}$ から $18 \mathrm{~m}$ までの 5 高度での 温度, 湿度の水平方向の变化を示す。湿度は, 最小值 0 , 最大值 1 と, 正規化された値とした。Fig. 2 には, 温度 について高度 $2 \mathrm{~m}$ での緑地の影響の範囲, 影響の強度に ついて図示した。緑地スケール $200 \mathrm{~m}, 300 \mathrm{~m}$ の場合 は, ほぼ, Fig. 2 と Fig. 3 の中間の值をとった。緑地の 規模が大きくなるにしたがい, 緑地上での温度の低下, 湿度の上昇は大きくなっている。

Fig. 2 と Fig. 3 の高さ $2 \mathrm{~m}$ の温度, 湿度を比較した 場合, 都市部から緑地に移ったときに温度は急激に低 
(a)

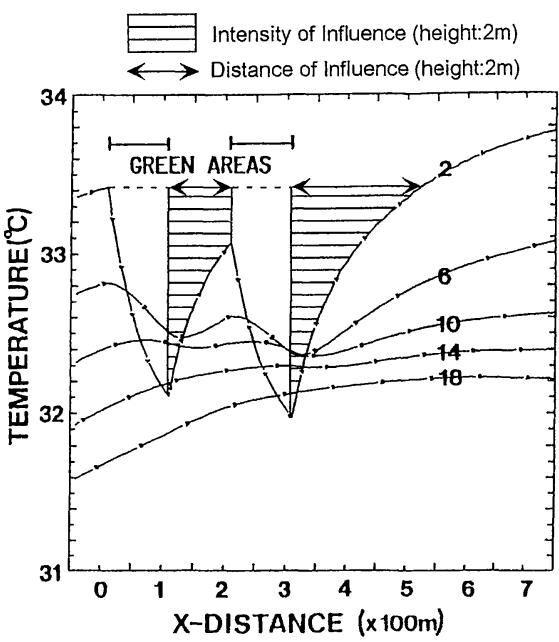

(b)

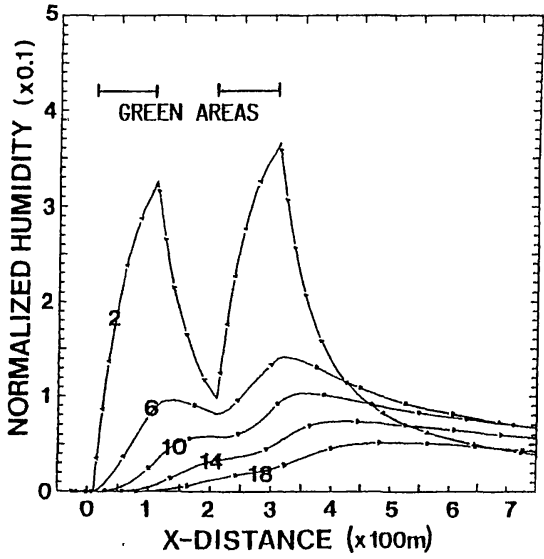

Fig. 4. Horizontal variation of (a) temperature and (b) normalized humidity near a green area (case of $100 \mathrm{~m}$ interval with two $100 \mathrm{~m}$ scale green areas).

下，湿度は急激に上昇する。Fig. 2, Fig. 3 ともに高度が 高くなるにしたがい, 緑地上での温度低下, 湿度の上昇 の度合は小さく, 都市部上に移ったときの温度の上昇, 湿度の低下屯ゆるやかである。また, Fig. 3 の場合で は, 風下に行くほよ゙, 緑地内の温度は下がるが, 単位距 離あたりの温度の低下する率は小さくなる。今回の計算 では, 都市部之緑地間の地表面温度差を $4{ }^{\circ} \mathrm{C}$ に設定した が,この程度の差であれば, 緑地スケールが $300 \mathrm{~m}$ 以上 になると高さ $2 \mathrm{~m}$ では温度, 湿度は变化が小さくなり, むしろ緑地スケールが大きくなるにしたがい，上空での 温度低下や湿度上昇がみられた。

\section{2 複数緑地上の温度と湿度の高度別変化}

Fig. 4 に緑地間隔 $100 \mathrm{~m}$, Fig. 5 緑地間隔 $200 \mathrm{~m}$ に, 緑地の間隔が変化した場合の高さ $2 \mathrm{~m}$ から $18 \mathrm{~m}$ までの (a)

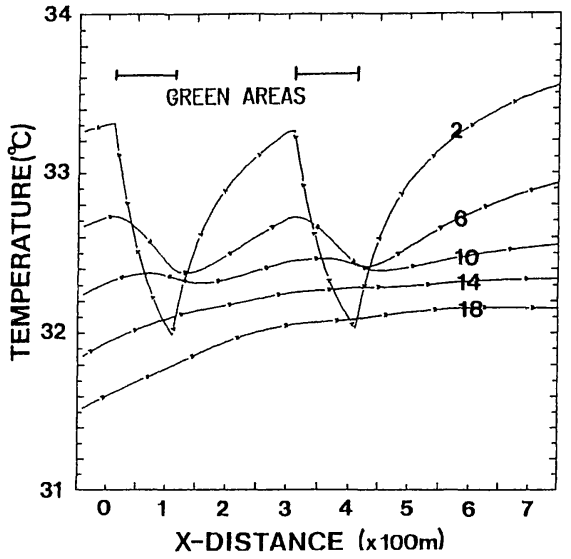

(b)

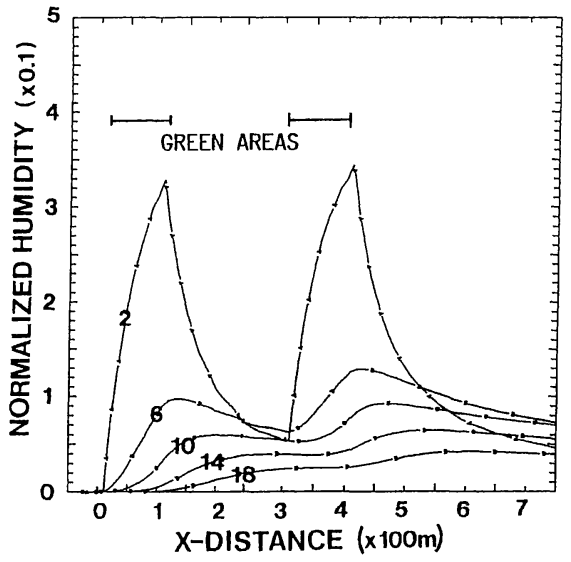

Fig. 5. Horizontal variation of (a) temperature and (b) normalized humidity near a green area (case of $200 \mathrm{~m}$ interval with two $100 \mathrm{~m}$ scale green areas).

5 高度での温度, 湿度の水平方向の変化を示す。

高さ $2 \mathrm{~m}$ での温度をみると, Fig. 4, Fig. 5 のすべて の緑地では, 緑地の規模が $100 \mathrm{~m}$ と小規模に設定した ため, Fig. 2 同様どの場合も緑地内での温度低下, 湿度 上昇は非常に急である。Fig. 4 では緑地の間隔が $100 \mathrm{~m}$ であり, 緑地間の都市部での温度上昇, 湿度低下は急で あるが, 風上の都市部温度まで上昇する前に, 2 番目の 緑地で再度温度低下している。また, 湿度もピーク值は, 風上の緑地の方が, 風下の緑地より小さい值をとってい る。Yun et al. (1998) の測定結果でも, 緑地間の都市 部において低温域が形成されることが示唆されている。 一方, Fig. 5 では緑地の間隔が $200 \mathrm{~m}$ であり, 緑地間の 都市部の温度は, 風上の都市部温度程度まで上昇し， 2 番目の緑地で再度低下している。湿度についてもピーク 值は, 風上の緑地と, 風下の緑地が同程度である。 


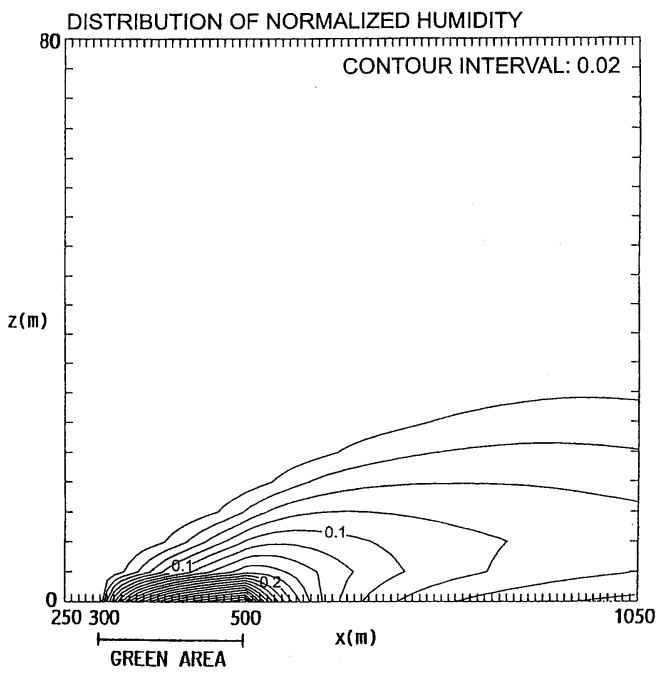

Fig. 6. Distribution of normalized humidity near a green area (case of $200 \mathrm{~m}$ scale green area).

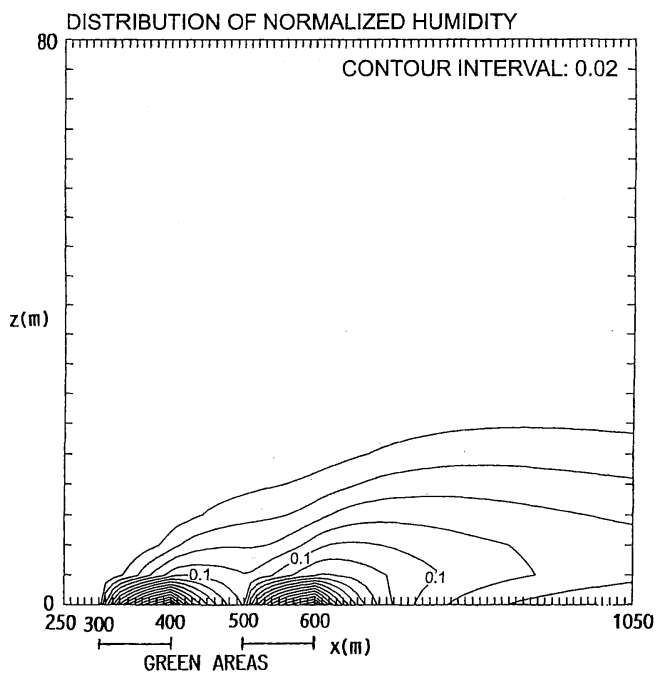

Fig. 7. Distribution of normalized humidity near a green area (case of $100 \mathrm{~m}$ interval with two 100 $\mathrm{m}$ scale green areas).

高さ $6 \mathrm{~m}$ 以上では, 高さ $2 \mathrm{~m}$ 之同様の傾向はみられ るものの, 温度, 湿度の変化は, 高度が高くなるにつれ ゆるやかになる。高さ $18 \mathrm{~m}$ では, Fig. 4 と Fig. 5 の温 度の差は非常に小さくなっている。

\section{3 温度, 湿度, 拡散係数の分布}

Fig. 6 に緑地スケール $200 \mathrm{~m}$ の場合の, 緑地付近の 湿度分布を示す。Fig. 7 には, 間隔 $100 \mathrm{~m}$ で 2 つの緑地 を配置した場合の湿度分布を示す。図から緑地の影響が どの程度の強度や範囲で及ぶかよくわかり, Fig. 7 で

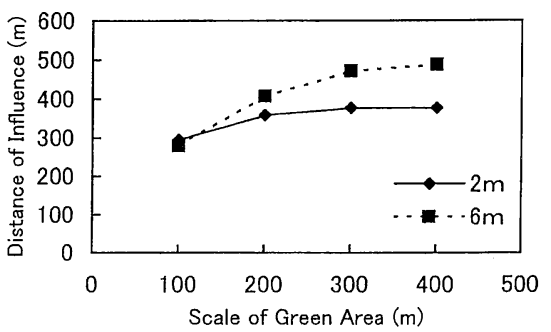

Fig. 8. Relation between scale of green areas and distance of influence.

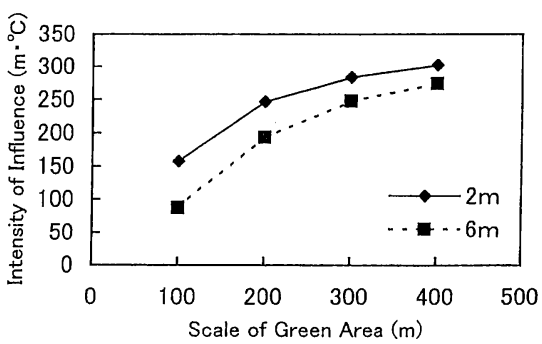

Fig. 9. Relation between scale of green areas and intensity of influence.

は，緑地間にも比較的高湿度域が形成される様子がわか る。

温度分布, 拡散係数の分布図は, 省略したが, 高湿度 の部分と, 温度分布での低温の部分は一致しており, 緑 地上や風下に低温部分が形成される。拡散係数の分布か らは, 緑地から都市部へと移るところで, 緑地が単一で あ複数のときであ拡散係数が大きな值をとる領域が形成 されることがわかった。低温域から高温域へ移行すると きに, 浮力が増大する影響によるものと考えられる。

また，様々なスケールの緑地付近の温度，湿度分布を 比較すると, 緑地スケールが大きくなるほど, 緑地の影 響による低温域，高湿度は垂直方向に範囲が広がる傾向 があることがわかった。

\section{4 緑地のスケールと影響の強度}

Fig. 1 に示すように, 緑地の影響の及ぶ範囲は, 温度 については, 緑地の風下端から温度が緑地の風上と同じ になる都市部上までの距離と定義し，影響の強度はその 間の温度を積分した值とした。Fig. 8 に緑地の規模と影 響の範囲の関係を, Fig. 9 に緑地の規模と影響の強度の 関係を，高度 $2 \mathrm{~m}$ と $6 \mathrm{~m}$ について示した。

Fig. 8 では, 高度 $2 \mathrm{~m}$ では, 緑地の影響の及ぶ範囲 は，緑地規模が， $300 \mathrm{~m}$ 以上では一定值になる。高度 6 $\mathrm{m}$ では, 緑地の影響の及ぶ範囲は, 高度 $2 \mathrm{~m}$ よりも大き な值をとり，また，増加率もスケールが大きくなるとと 


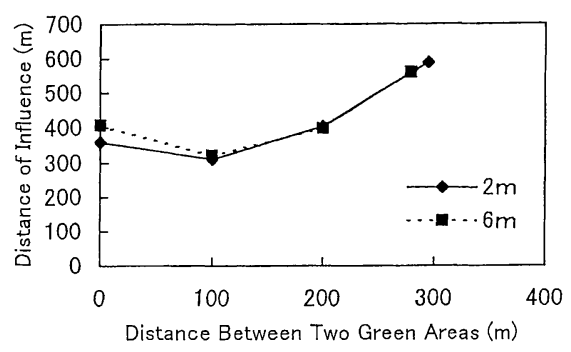

Fig. 10. Relation between interval of green areas and distance of influence.

あに小さくなるが，高度 $2 \mathrm{~m}$ よりあ大きな値をとる。

Fig. 9 の影響の強度については, દ゙ちらの高度でも， 緑地の規模が大きくなれば，増加する傾向がみられた が，緑地の規模が大きくなるにしたがい，単位距離当た りの増加量は減り, 一定值に近づく傾向がみられた。

したがって, 高度 $2 \mathrm{~m}, 6 \mathrm{~m}$ での単位スケール当たり の緑地の影響を考えると, $100 \mathrm{~m}$ のスケールの緑地が $400 \mathrm{~m}$ の緑地よりも影響が大きくなっているといえる。

また, 温度分布, 湿度分布からみると, スケールが大 きくなるほど, 緑地の影響による低温域, 高湿度域は垂 直方向に範囲が広がる傾向がある。

\section{5 複数緑地の間隔の影響}

Fig. 4, Fig. 5 のように複数の緑地があるとき， 前述 の定義より緑地間の都市部も影響の範囲に含まれるとし た。高さ $2 \mathrm{~m}$ の影響の範囲を Fig. 4 に図示した。緑地 の間隔と, 影響の範囲の関係を Fig. 10 に, 影響の強度 との関係を Fig. 11 に示した。間隔 $0 \mathrm{~m}$ は, $200 \mathrm{~m}$ の緑 地の場合の值を使用した。右端の間隔 $300 \mathrm{~m}$ の緑地に おけるデー夕は，スケール $100 \mathrm{~m}$ の緑地とその影響が 及ぶ範囲が, Fig. 8 より, 高度 $2 \mathrm{~m}, 6 \mathrm{~m}$ の場合とも, 約 $300 \mathrm{~m}$ であったため, 緑地の間隔が $300 \mathrm{~m}$ 以上の場合 には, 緑地の影響の範囲や強度は变らないと仮定し, ス ケール $100 \mathrm{~m}$ の緑地の影響範囲を 2 倍した值を用いた。

Fig. 10 では，緑地の影響の及ぶ範囲は，緑地の間隔 が大きくなるにしたがい，間隔 $100 \mathrm{~m}$ ではやや小さく なるが，その後大きくなっている。前述のように，間隔 $300 \mathrm{~m}$ 以上では緑地の影響の及ぶ範囲は, 一定值となる と考えられる。Fig. 11 の緑地の影響の強度についても, 同様の傾向がみられた。

したがって, 複数の緑地を設ける場合, 緑地の影響の 範囲や強度に関しては, 間隔 $300 \mathrm{~m}$ かあるいはそれ以 上にした場合に, 影響の範囲, 強度は最大となるので, その間隔で配置するのが効果的に気温を低下させると考 えられる。また，一般的に複数の緑地の配置を行う場合 には,このような, 最適な緑地の間隔が存在すると考え

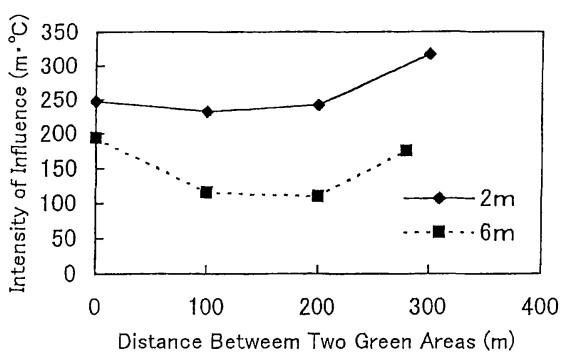

Fig. 11. Relation between interval of green areas and intensity of influence.

られる。

\section{6 都市緑地の設計と緑地規模について}

今回のシミュレーションは, 2 次元モデルであり 3 次 元的にみると奥行き方向が同一状態を仮定していること になる。したがって，緑地帯の影響とみることができ， 緑地のスケールあ長さで表された。

Fig. 8 や Fig. 9 に示したような緑地の規模と影響の 範井, 強度との関係から, 緑地の影響をできるだけ風下 側に大きくとりたい場合は大規模緑地がよいことが予測 される。我々が生活している地表数 $\mathrm{m}$ 付近での, 単位長 さの緑地当りの影響を大きくしたい場合は, ある程度の 小規模緑地が効率的であるといえる。

これらの值は, 地表面でのパラメータや, モデルの仮 定が異なれば当然異なるので, 緑地の設計時には具体的 事例ごとに同様な計算を行う必要がある。実際の 3 次元 での緑地は, 奥行き方向のスケールが有限である。2次 元の場合, 奥行き方向のスケールが無限之みなされるの で， 3 次元の場合には二次元の場合に比べて, 緑地が都 市の影響を受けるため, 緑地の風下方向の温度低下の程 度は弱まるであろうが, 地表付近での単位面積あたりの 影響という観点からは, 小規模の緑地が効率的であり大 規模の緑地では効果が一定に近づくという傾向はほぼ同 じであると考えられる。

\section{7 都市緑地の設計と緑地の間隔について}

複数の緑地を設ける場合についても, シミュレーショ ンが 2 次元モデルであり 3 次元的にみると奥行き方向 が同一状態を仮定していることになり，実際には二次元 の場合より風下方向の温度低下の程度は弱まるである う。複数の緑地を設ける場合, ある程度距離をおいて配 置した方が効果的に気温を低下させるという傾向はほぼ 同じであると考えられる。

都市全体のスケールでみた緑地の配置については，緑 地による熱的影響のみを考えた場合, 特に, 夏期の地表 付近の微気象緩和のためには, 緑地の総面積が同じであ れば，最適なスケールと間隔で緑地を分散して配置する 
のがよいといえるであろう。

\section{4. まと め}

都市緑地上の風速, 温度分布などを予測するため, $k-\varepsilon$ 2 方程式モデルを使用して，緑地のスケールが変化した ときや，複数の緑地が存在したときのシミュレーション を行った。

その結果，スケールの大きな緑地ほど大きな影響の強 度を示すが，単位スケール当たりの影響の強さは，小さ な緑地の方が大きいことや，また，スケールが大きくな るほど，緑地の影響による低温域は垂直方向に及ぶ範囲 が広がる傾向があることが示された。

また, 複数の緑地が存在し, 緑地間隔が変化した場合 のシミュレーションを行った結果, 地表付近では, 緑地 間の都市部にあ相対的な低温域が形成されることや，そ の温度低下の程度は, 緑地間隔により異なることがわ かった。

総面積が同じであれば，適度な間隔で緑地を分散して 配置する方が，地表付近の温度低下や，湿度上昇には効 果があることが示唆された。

今回のシミュレーションは，非常に限られたケースの あのであった。実際の現象は 3 次元であるため，今後 は，モデルの 3 次元化を行い解析することが必要である う。また，計算結果を気象観測と比較し検証することも， 今後の課題である。

\section{引用 文 献}

Bill, R.G., Chen, E., Sutherland, R.A. and Bartholic, X., 1979: Simulating the moderating effect of a lake on downwind temperature. Bound.Layer Meteorol., 16, 23-33.

Bornstein, R.D., 1975: The two-dimensional URBMET urban boundary layer model. J. Appl. Meteorol., 14, 1459-1477.

Estoque, M.A., 1961: Theoretical investigation of the sea breeze. Quart. J. R. Met. Soc., 87, 136-146.
Estoque, M. A. and Bhumralkar, C.M., 1969: A method for solving the planetary boundary equations. Bound.-Layer Meteorol., 1, 169-194.

Gutman, D. P. and Torrance, K. E., 1975: Response of the urban boundary layer to heat addition and surface roughness. Bound.-Layer Meteorol., 9, 217-233.

Honjo, T. and Takakura, T., 1984: Thermal effect of greenspace in urban area (1) Energy budget analysis based on the micrometeorological observation. J. Agric. Meteorol., 40, 257-261.

Honjo, T. and Takakura, T., 1986: Analysis of temperature distribution of urban green spaces using remote sensing data. J. Jpn. Inst. Landsc. Archit., 49, 299-304.

Honjo, T. and Takakura, T., 1990/1991: Simulation of thermal effects of urban green area on their surrounding areas. Energy and Buildings, 15-16, 443-446.

Honjo, T. and Takakura, T., 2000: Validation of the $k-\varepsilon$ model for analysis of the thermal effect of urban green area. J. Agric. Meteorol., 56, 243-251.

Kanda, M. and Hino, M., 1990: Numerical Simulation of Soil-Plant-Air System (2) Numerical experiment on the effect of plant on meteorological environment. J. Jpn. Soc. Hydrol. Water Resour., 3, 47-55.

Lee, R. L. and Olfe, D. B., 1974: Numerical calculations of temperature profiles over an urban heat island. Bound.-Layer Meteorol., 7, 39-52.

McElroy, J. L., 1973: A numerical study of the nocturnal heat island over a medium-sized midlatitude city. Bound.-Layer Meteorol., 3, 442-453.

$\mathrm{Yu}$, T.W. and Wagner, N. K., 1975: Numerical study of the nocturnal urban boundary layer. Bound.-Layer Meteorol., 9, 143-162.

Yun, Y., Maruta, Y., Honjo, T. and Yanai, S., 1998: A study on the relations between scale and green spaces and decreasing air temperature of surrounding urban area. Papers on Environmental Information Science, No. 12, 275-280. 